\title{
Evaluation of high-concentrate diets that vary in physically effective neutral detergent fibre for finishing lambs
}

\author{
H.H.A. Costa ${ }^{1}$, M.C.P. Rogério ${ }^{2 \#}$, R.C.F.F. Pompeu ${ }^{2}$, R.N.B Lôbo ${ }^{2}$, A.R. Lima ${ }^{2}$, C.S. Costa ${ }^{3}$, \\ E.S. Pereira ${ }^{3}$, L.F. Guedes ${ }^{2}$ \& J.P. Muir ${ }^{4}$ \\ ${ }^{1}$ Department of Animal Science, Universidade Estadual Vale do Acaraú, Avenida da Universidade, Campus Betânia, \\ Sobral, CE, Brazil, 850, 30.123-970 \\ ${ }^{2}$ Brazilian Agricultural Research Corporation, Embrapa Goats \& Sheep, Estrada Sobral-Groaíras, Km 04, Sobral, Ceará, \\ Brazil 62.011-970 \\ ${ }^{3}$ Animal Science Department, Centro de Ciências Agrárias, Federal University of Ceará. Campus Pici, Avenida Mister \\ Hull, Bloco 808, Fortaleza, Ceará, Brazil, CEP:60.455-760 \\ ${ }^{4}$ Texas A\&M AgriLife Research, 1229 North U.S. Hwy 281, Stephenville, TX 76401, USA
}

(Submitted 22 November 2019; Accepted 15 January 2020; Published 7 May 2021)

\author{
Copyright resides with the authors in terms of the Creative Commons Attribution 4.0 South African Licence. \\ See: http://creativecommons.org/licenses/by/4.0/za \\ Condition of use: The user may copy, distribute, transmit and adapt the work, but must recognize the authors and the South African \\ Journal of Animal Science.
}

\begin{abstract}
The objective of this research was to evaluate lamb diets with a high proportion of concentrate and various levels of physically effective neutral detergent fibre (NDF) using tropical ingredients. Four diets were formulated: D1 with $16.5 \%$ physically effective NDF (peNDF), D2 with $21.4 \%$ peNDF, D3 with $23.3 \%$ peNDF, and D4 with $24.6 \%$ peNDF. Twenty male Santa Inês lambs at four months old with an average liveweight (LW) of $18.6 \pm 3.4 \mathrm{~kg}$ were fed for 49 days. There were no differences $(P>0.05)$ among the diets in dry matter (DM) intake. Crude protein (CP) intake, relative to either $L W$ or metabolic live weight $\left(\mathrm{LW}^{0.75}\right)$ or $\mathrm{LW}$, was greater $(P \leq 0.05)$ for D2 and D3 than for D1 or D4. Lower $(P \leq 0.05)$ NDF intake, relative to LW 0.75 or LW, was lower for D1 than for the other diets. Selection indexes (SIs) were similar $(P>0.05)$ among diets. Animals that consumed D1 had less $(P \leq 0.05)$ rumination time per bolus. Meaningful variations were not observed in performance and efficiency of finishing lambs that were related to differences in peNDF among the diets. Santa Inês lambs were able to adapt to diets with low levels of peNDF by increasing rumination time as a consequence of increased fibre consumption and greater particle size selection.
\end{abstract}

Keywords: agro-industrial by-products, average particle size, rumen bypass protein, sheep, tropical feedstuffs

\#Corresponding author: marcos.claudio@embrapa.br

\section{Introduction}

Native Caatinga rangelands of north-eastern Brazil represent up to $90 \%$ of the feed source for sheep in that region (Costa et al., 2019). Forage potential of these semi-arid rangelands and seasonal changes in vegetation depend on climatic conditions, so quantity and quality peak for a few months of the year (Araújo Filho, 2013). In addition, most of the plant species in the Caatinga pastures are not selected by grazing sheep (Santos et al., 2010).

Therefore, feeding lambs in confinement becomes a viable alternative during low forage availability. A large part of the cost of production is linked to food. Therefore, evaluating alternative diets for sheep in confinement is necessary owing to the diversity of local ingredients. These evaluations can provide recommendations for feedstuffs that could minimize costs with minimal effect on animal performance. When balancing diets for confined animals, the fibre content of the ration requires attention. Ruminant animals need fibre in their diet to maintain adequate ruminal fermentation and consequently their health (Sousa et al., 2018). Gallo et al. (2019) found that a high-concentrate diet with $15 \%$ NDF produced better weight gain in finishing lambs than diets that were higher in fibre.

The physical and chemical characteristics of the feed modify feeding behaviour by affecting the motility of the fore-stomach, the rate of passage and the supply of nutrients to the animal (NRC, 2007). 
Mastication for example is related to the size of the feed particle that reaches the rumen and can affect feed digestibility and consequently intake (Francisco et al., 2020). Feed intake studies identify feeding habits that dictate whether small ruminants attain nutrient intake that meets their nutritional needs. In this type of study, parameters such as duration and frequency of feed intake, rumination and mastication become important (Nicory et al., 2015).

Offering feeds with varying average particle sizes (APS) and densities often allows for feed separation during mixing and transport, and for diet selection by animals. Particle size therefore can be important for predicting feed value (Leonardi et al., 2005). Variations in APS can cause the nutritive value of feed that is ingested to differ from what is offered. Sheep breeds such as the Santa Inês, which are adapted to Brazilian semi-arid rangelands, use diets that are high in fibre, but low in peNDF by increasing rumination time through selection of smaller APS from feed.

The objective of this research was to evaluate diets formulated for lambs with tropical ingredients that had a high proportion of concentrate and various levels of peNDF. Effects on intake, performance, diet selection, and feeding behaviour were of primary interest

\section{Materials and Methods}

The experimental protocol was approved by the Animal Experiment Committee of the Universidade Estadual Vale do Acaraú (Ethics Committee approval no. 031.12/2007). The trial was conducted at Universidade Estadual Vale do Acaraú, Sobral, in the Sertão Cearense zone at $3^{\circ} 36^{\prime}$ south, $40^{\circ} 18^{\prime}$ west, at an evaluation of $56 \mathrm{~m}$.

Native grass silage was obtained from a Type VI unit of the Brazilian Caatinga forest on the banks of a river, with Gaussen xerothermic indices varying between 150 and 200 (Andrade-Lima, 1981). The woody vegetation was thinned to reduce canopy suppression of the herbaceous stratum by $35 \%$ to $40 \%$. Forage was harvested when $50 \%$ of the plants were flowering to standardize the material to be ensiled and ensure balance of quality and quantity.

Species in native pasture that was ensiled for this trial included Borreria verticillata G.F.W. Mayer, Commelina diffusa M.F. Burn, Sida cordifolia, Digitaria sanguinalis (L.). Scop, Arachis pintoi, Calotropis procera, Stylosanthes humilis, Ipomea glabra Choisy, and Jacquemontia asarifolia L.B. Smith. These were harvested in the rainy season from March to May, mixed with $13 \%$ wheat bran, and ensiled in $200 \mathrm{~L}$ plastic barrels ( $n=5$ per month). Ingredients used in the diets for finishing the lambs included native pasture silage, annatto by-product, obtained from the extraction of the apocarotenoid food colouring from the seeds, soybean meal (Glycine max (L.) Merr.) obtained from oil extraction, ground maize (Zea mays L.) and limestone (Table 1).

Laboratory analyses of the feedstuffs were carried out at the Animal Nutrition Laboratory of the Animal Science Department at Universidade Estadual Vale do Acaraú. To determine DM, OM, ash, ether extract (EE), and CP contents, AOAC (1990) methods were followed. Methods described by Van Soest et al. (1991) were used to determine NDF, acid detergent fibre (ADF), cellulose (CEL), hemicellulose (HCEL), and acid detergent lignin (ADL). The Cornell System (Sniffen et al., 1992) was used to determine total carbohydrates (TCHO), and the total digestible nutrient (TDN) content was determined from the proximate analysis of the diets. The equation described by Weiss (1993) was used to determine non-fibrous carbohydrate (NFC).

The diets were formulated to meet the requirements of growing lambs between four and seven months old with average live weight (LW) of $20 \mathrm{~kg}$ that were gaining $200 \mathrm{~g} / \mathrm{d}$ (NRC 1985, 2007). The treatments (D1, D2, D3, and D4 contained 16.5\% (NRC, 1985), 21.4\%, 23.3\%, and $24.6 \%$ (NRC, 2007) peNDF, respectively (Table 2).

Twenty male Santa Inês lambs, approximately four months old and weighing an average of $18.6 \pm 3.4$ $\mathrm{kg}$, were assigned in a completely randomized design to the four diet treatments (five lambs per treatment diet). Each lamb was housed in a $1.5 \mathrm{~m} \times 1.0 \mathrm{~m} \times 0.8 \mathrm{~m}$ pen fitted with feeders, watering devices and plastic salt holders and was deemed sufficient for its comfort. The building that contained the pens (Núcleo de Pesquisa em Nutrição de Pequenos Ruminantes) was $196 \mathrm{~m}^{2}$, with concrete floors, $7 \mathrm{~m}$ high walls and a tile roof that allowing for air circulation and thus afforded comfortable temperatures. There was no inter-animal competition for feed and space, and environmental enrichment (jolly balls) was provided in the pens. The animals were fed twice a day (at $07 \mathrm{~h} 00$ and 16h00) during the experiment. One month before the study, all lambs were examined for disease, dewormed, and vaccinated against clostridia by a licensed veterinarian. Consumption was measured as the difference between feed offered and orts in a 24-hour period. Rejected orts were weighed each day and the following day's feed was adjusted to achieve $15 \%$ to $20 \%$ excess to provide for ad libitum consumption. Water and mineralized salt were provided ad libitum. Samples of feed and orts were collected weekly in the morning (07h00). 
Table 1 Nutritional analysis of feedstuffs used in formulating diets that differed in the level of physically effective neutral detergent fibre for finishing lambs

\begin{tabular}{|c|c|c|c|c|c|}
\hline Nutrients & $\begin{array}{c}\text { Native grass } \\
\text { silage }\end{array}$ & Annatto & Soybean meal & Maize & Limestone \\
\hline Dry matter, $\%$ as is basis & 33.5 & 87.3 & 87.3 & 87.4 & 100.0 \\
\hline \multicolumn{6}{|l|}{ Composition, \% of dry matter } \\
\hline Organic matter & 82.6 & 88.6 & 90.8 & 92.7 & \\
\hline Crude protein & 13.0 & 14.9 & 52.6 & 10.1 & \\
\hline Neutral detergent fibre (NDF) & 53.5 & 43.2 & 24.2 & 15.6 & \\
\hline NDF (corrected for ash and protein) & 37.5 & 31.4 & 12.9 & 11.5 & \\
\hline Acid detergent fibre (ADF) & 33.3 & 27.1 & 11.0 & 3.9 & \\
\hline Ether extract & 2.37 & 1.12 & 0.94 & 1.51 & \\
\hline Hemicellulose & 20.2 & 16.0 & 13.1 & 11.7 & \\
\hline Cellulose & 26.3 & 18.5 & 10.4 & 3.5 & \\
\hline Lignin & 5.9 & 6.1 & 0.6 & 0.5 & \\
\hline Total carbohydrate & 73.5 & 77.5 & 39.8 & 87.0 & \\
\hline Non-fibre carbohydrate & 35.9 & 46.1 & 26.9 & 75.5 & \\
\hline Gross energy, Mcal/kg & 3.25 & 3.95 & 4.42 & 4.33 & \\
\hline Total digestible nutrients & 58.8 & 59.8 & 71.6 & 80.9 & \\
\hline Nitrogen (N) in NDF as \% of total $\mathrm{N}$ & 40.3 & 31.5 & 8.4 & 10.6 & \\
\hline $\mathrm{N}$ in $\mathrm{ADF}$ as $\%$ of total $\mathrm{N}$ & 3.1 & 14.7 & 1.0 & 1.9 & \\
\hline Particles > 19 mm, \% & 74.3 & & & & \\
\hline Particles between 8 and $19 \mathrm{~mm}, \%$ & 2.2 & & & & \\
\hline Particles between 1.18 and $8 \mathrm{~mm}, \%$ & 10.4 & 7.9 & 14.1 & 91.4 & 93.7 \\
\hline Particles $<1.18 \mathrm{~mm}, \%$ & 13.1 & 92.1 & 85.9 & 8.6 & 6.3 \\
\hline
\end{tabular}

Confinement lasted 49 days, that is, 10 days for adaptation and 39 days for data collection. Animals were weighed at the beginning of the adaptation period to adjust feed on offer and percentages of leftovers, which were measured as g DM/kg LW ${ }^{0.75}$ (Schneider \& Flatt, 1975). The animals were subsequently weighed every seven days, starting on day 7 , after 16 hours without feed. Intake was calculated as $\mathrm{g} / \mathrm{kg} \mathrm{LW}^{0.75}$ and $\mathrm{g} / \mathrm{d}$, whereas DM, organic matter (OM), CP and NDF intake were calculated only as percentages of LW. The differences between final LW and initial LW were used to calculate average daily gain (ADG) and feed efficiency.

Feeding behaviour was monitored on days 18 and 19 of the trial. During a 24-hour period, time spent ingesting feed, ruminating, idling and other activities that were not related to ingestion, rumination and idling were recorded every five min (Johnson \& Combs, 1991). On the 19th day, the average number of mastications and time spent masticating per bolus was obtained during three two-hour periods from $10 \mathrm{~h} 00$ to $12 \mathrm{~h} 00,14 \mathrm{~h} 00$ to $16 \mathrm{~h} 00$, and $18 \mathrm{~h} 00$ to $20 \mathrm{~h} 00$ (Bürger et al., 2000). A digital chronometer was used to measure time. Artificial illumination was used throughout the trial so that the lambs were adapted to the conditions for observation. Feeding behaviour data were summarized (Polli et al., 1996). Total feeding time was the sum of times spent ingesting and ruminating. Number of boluses (NDB) was the ratio of rumination time and rumination time per bolus. Number of mastications was the product of number of mastications per bolus and NDB. Efficiencies of intake (IE) and rumination (RE) were calculated as ratios of intake and time spent ingesting feed and ruminating, respectively. A bolus was defined as that portion of the feed that was regurgitated to the mouth for remastication during rumination. Samples of the feedstuffs and orts were used to measure APS. Samples were collected every seven days. At the end of the trial, samples from each animal were pooled. Average particle size was measured using sieves in a Penn State particle size separator (University Park, Pennsylvania, USA) (Lammers et al., 1996). This separator had four trays that retained particles greater than $19 \mathrm{~mm}, 19 \mathrm{~mm}$ to $8 \mathrm{~mm}, 8 \mathrm{~mm}$ to $1.18 \mathrm{~mm}$, and less than $1.18 \mathrm{~mm}$. The APS of the diet was estimated as the proportion of the diet of each feedstuff multiplied by the proportional contribution of each particle size category to the total. The average particle size data are described in Table 
1. Four fractions (> $19 \mathrm{~mm}, 19$ to $8 \mathrm{~mm}, 8$ to $1.18 \mathrm{~mm}$ and $<1.18 \mathrm{~mm}$ ) for the diets, orts, and effective consumption were calculated for each animal, adjusted to $100 \%$.

Table 2 Ingredients in experimental diets for finishing lambs that differed in physically effective neutral detergent fibre and nutritional composition

\begin{tabular}{lcccc}
\hline Ingredients & D1 & D2 & D3 & D4 \\
\hline Native pasture silage including 13\% wheat bran & 15.3 & 32.6 & 37.5 & 40.8 \\
Annatto by-product & 11.6 & 11.2 & 10.9 & 11.0 \\
Soybean meal & 11.3 & 18.2 & 15.0 & 13.1 \\
Maize & 60.6 & 36.7 & 35.3 & 33.8 \\
Limestone & 1.3 & 1.3 & 1.3 & 1.3 \\
Nutritional composition & & & & \\
Dry matter (DM), \% as fed & 79.4 & 70.0 & 67.3 & 65.6 \\
Organic matter, \% DM & 94.7 & 92.6 & 92.3 & 92.2 \\
Crude protein, \% DM & 15.7 & 19.1 & 18.0 & 17.3 \\
Ether extract, \% DM & 1.51 & 1.62 & 1.68 & 1.72 \\
Neutral detergent fibre (NDF), \% DM & 25.4 & 32.5 & 34.3 & 35.8 \\
Acid detergent fibre, \% DM & 11.8 & 17.3 & 18.4 & 19.3 \\
Lignin, \% DM & 2.00 & 2.92 & 3.17 & 3.35 \\
Total carbohydrates, \% DM & 77.5 & 71.8 & 72.6 & 73.1 \\
Non-fibrous carbohydrates, \% DM & 59.6 & 49.5 & 49.1 & 48.8 \\
Neutral detergent fibre nitrogen (N), \% total N & 15.8 & 17.9 & 19.6 & 20.8 \\
Percent NDF from forage & 8.2 & 17.4 & 20.0 & 21.8 \\
Physically effective NDF & 16.5 & 21.4 & 23.3 & 24.6 \\
Acid detergent fibre N, \% total N & 3.12 & 2.82 & 2.98 & 3.11 \\
Total digestible nutrients & $73.0 \pm 0.7$ & $67.7 \pm 0.7$ & $68.8 \pm 0.7$ & $66.9 \pm 0.7$ \\
\hline
\end{tabular}

D1, D2, D3, D4: diets providing $16.5 \%, 21.4 \%, 23.3 \%$ and $24.6 \%$ physically effective neutral detergent fibre, respectively

Selection among dietary constituents was quantified as proposed by Leonardi and Armentano (2003). Predicted intake was as-fed intake for the total diet multiplied by the as-fed fraction of that particle size in the diet. Observed intake was the difference between the percentage of a particular particle size category in the diet as-fed and the percentage of a particular particle size in the orts. The ratio of observed intake to predicted intake was used as a metric to quantify dietary selection with values less than $100 \%$ indicating rejection, values greater than $100 \%$ indicating preference, and values equal to $100 \%$ indicating the absence of selection.

Because the lambs were fed individually, they were considered the experimental units. Thus, there were three degrees of freedom for the fixed effects of diets and 15 degrees of freedom of random residual variance in the analyses of variance for consumption, feeding behaviour and performance. Data were tested for normality and homoscedasticity prior to analyses of variance using PROC UNIVARIATE (SAS Institute Inc., Cary North Carolina, USA). The linear model used for these analyses was:

$$
Y_{i j}=\mu+d_{i}+e_{i j}
$$

where: $Y_{i j}$ was a dependent variable measured on the jth lamb consuming the ith diet (d), $\mu$ was the overall mean, and $e_{i j}$ was the random residual error. Means of the diet effects were compared using Tukey's test at $5 \%$ probability.

Indexes of selection (SI) among dietary constituents were analysed with a repeated measures analysis of variance using PROC MIXED (SAS Institute Inc., Cary North Carolina, USA). The covariance structure for 
the variance among experimental units was chosen using Akaike's information criterion. The linear model used for this analysis was:

$$
Y_{i j k}=\mu+d_{i}+l_{i j}+p s_{k}+d p s_{i k}+e_{i j k}
$$

where: $Y_{i j k}$ was a measurement of $\mathrm{SI}$ from an individual lamb that consumed the ith diet, $\mu$ was the overall mean, $l_{i j}$ was the random effect of the jth lamb (analogous to the residual error in the first model), $p s_{k}$ was the effect of the $k^{\text {th }}$ particle size category, $d p s_{i k}$ was the effect of the interaction between dietary treatment and particle size category, and $e_{i j k}$ was the random residual error. Means were again contrasted at the $5 \%$ level of probability.

\section{Results and Discussion}

Diets for finishing lambs generally require the inclusion of a greater amount of concentrate. In the present experiment this resulted in higher proportions of particles smaller than $8 \mathrm{~mm}(8-1.18 \mathrm{~mm}$ and less than $1.18 \mathrm{~mm}$ ). The greatest proportion of particles between 8 and $1.18 \mathrm{~mm}$ was found in D1 (Figure 1), which contained $73 \%$ concentrate. That diet was fed at a rate of $1126 \mathrm{~g} / \mathrm{lamb} / \mathrm{d}$ with $208 \mathrm{~g} / \mathrm{lamb} / \mathrm{d}$ refused, resulting in $918 \mathrm{~g} / \mathrm{lamb} / \mathrm{d}$ being consumed. Diet D2 was fed at $1173 \mathrm{~g} / \mathrm{lamb} / \mathrm{d}$ with $969 \mathrm{~g} / \mathrm{lamb} / \mathrm{d}$ being consumed. Diet D3 was fed at $1127 \mathrm{~g} / \mathrm{lamb} / \mathrm{d}$ with $963 \mathrm{~g} / \mathrm{lamb} / \mathrm{d}$ being consumed. Finally, D4 was fed at $1037 \mathrm{~g} / \mathrm{lamb} / \mathrm{d}$ with $868 \mathrm{~g} / \mathrm{lamb} / \mathrm{d}$ being consumed.

No differences among treatments were detected in dry matter intake (DMI) or organic matter intake (OMI), whether expressed as $\mathrm{g} / \mathrm{kg} \mathrm{LW}{ }^{0.75}$ or percentage LW (Table 3). Lambs fed D2 and D3 had greater CP intake compared with D1 and D4 because of the greater proportion of CP in those diets. D2 had greater NDF intake than D1. There were no differences in ADG and feed efficiency among treatments.

No interaction effects were detected between diet and particle size that affected diet selection by the lambs. The lambs refused feed equally across diets (Table 4). However, the differences among particle size categories were significant, indicating that the lambs sorted their feed according to particle size (Table 4). Small particle sizes and very large particles were consumed without apparent sorting. However, particles between 1.18 and $8 \mathrm{~mm}$ were rejected relative to their contribution to the diets.

No differences were detected among treatments for time spent ingesting, ruminating, masticating, resting or other activities (Table 5). Likewise, DMI, NDF intake, and the rates reflecting efficiencies of intake, DM rumination, and NDF rumination were not affected significantly by the dietary treatments (Table 6). The lambs fed D1 spent less time ruminating each bolus than the lambs that were fed diets that were higher in physically effective NDF.

Daily intake can be described by the number of times lambs feed, time spent feeding, and feed intake rate. The quantity of feed intake may vary by $40 \%$ to $60 \%$, depending on factors inherent in individual animals, by $20 \%$ to $30 \%$, depending on the characteristics of feed on offer, and by $10 \%$ to $15 \%$, depending on environment and management (Van Soest, 1994). This confirms that management can affect feeding behaviour, which will result in altered animal performance, and the economic viability of the production system (Eustáquio Filho et al., 2014; Custodio et al., 2016).

Sheep are able to ingest high amounts of energy and low fibre without drastically changing the consumption of dry material (Gallo et al., 2019). In the present study, the average DMI was greater than that reported by Moreno et al. (2010) for lambs fed tropical diets. Macedo Junior et al. (2006) reported that Santa Inês sheep fed forage with $35 \%$ NDF consumed CP at $17 \mathrm{~g} / \mathrm{kg} \mathrm{LW}^{0.75}$ and NDF at $33 \mathrm{~g} / \mathrm{kg} \mathrm{LW}^{0.75}$, which was greater than the intake levels observed in this study. For finishing lambs, NRC (2007) recommends $64.5 \mathrm{~g}$ $\mathrm{DMl} / \mathrm{kg} \mathrm{LW} \mathrm{LW}^{0.75}$ and $12.3,11.7$ and $11.3 \mathrm{~g} \mathrm{CP} / \mathrm{kg} \mathrm{LW}{ }^{0.75}$ when fed rumen-undegradable protein levels of $20 \%$, $40 \%$ and $60 \%$, respectively. In the present study, intake levels were greater than these recommendations.

In the present study, ADG averaged $242.5 \mathrm{~g} / \mathrm{d}$ across all diets. Thus, these Santa Inês lambs grew more slowly than those that were studied by Moreno et al. (2010), who reported gains of $314.3 \mathrm{~g} / \mathrm{d}$. Medeiros et al. (2007), who studied Morada Nova lambs that were fed various levels of concentrate, reported less efficient feed conversion $(7.23 \mathrm{~kg} / \mathrm{kg})$ than was observed in this study ,in which the feed conversion averaged $3.70 \mathrm{~kg} / \mathrm{kg}$. Thus, it is possible that diets with $15 \%$ NDF were safe for lambs, as they did not affect animal health adversely or the digestion of feedstuffs (Costa et al., 2013; Gallo et al., 2019). 
(A)

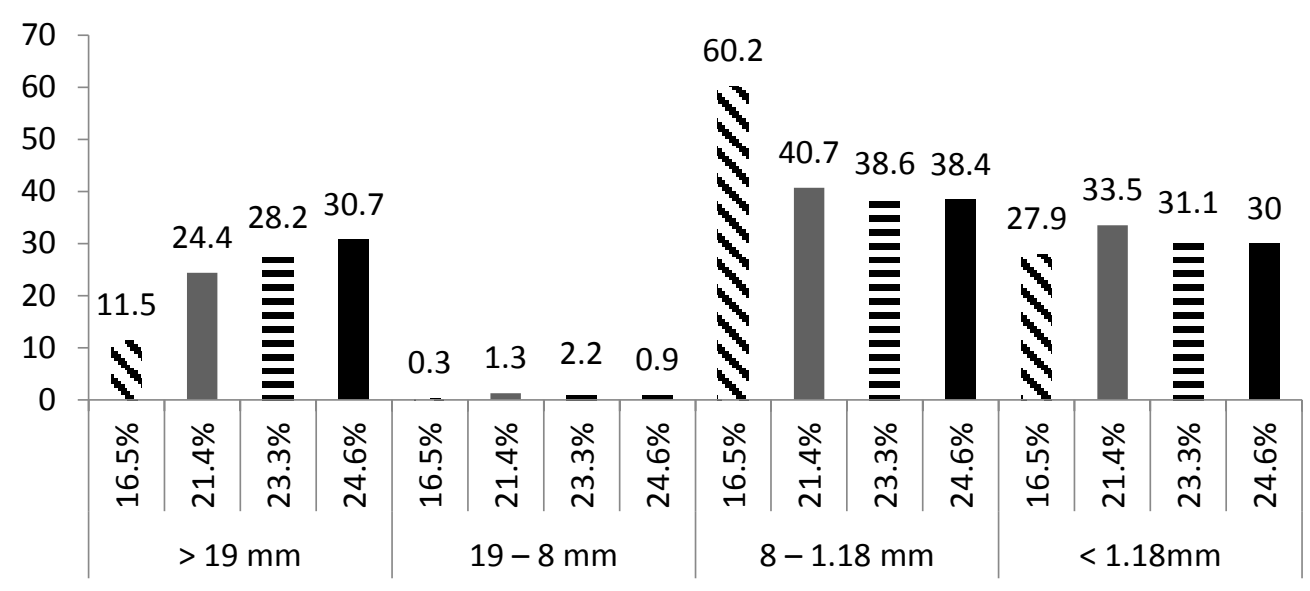

(B)

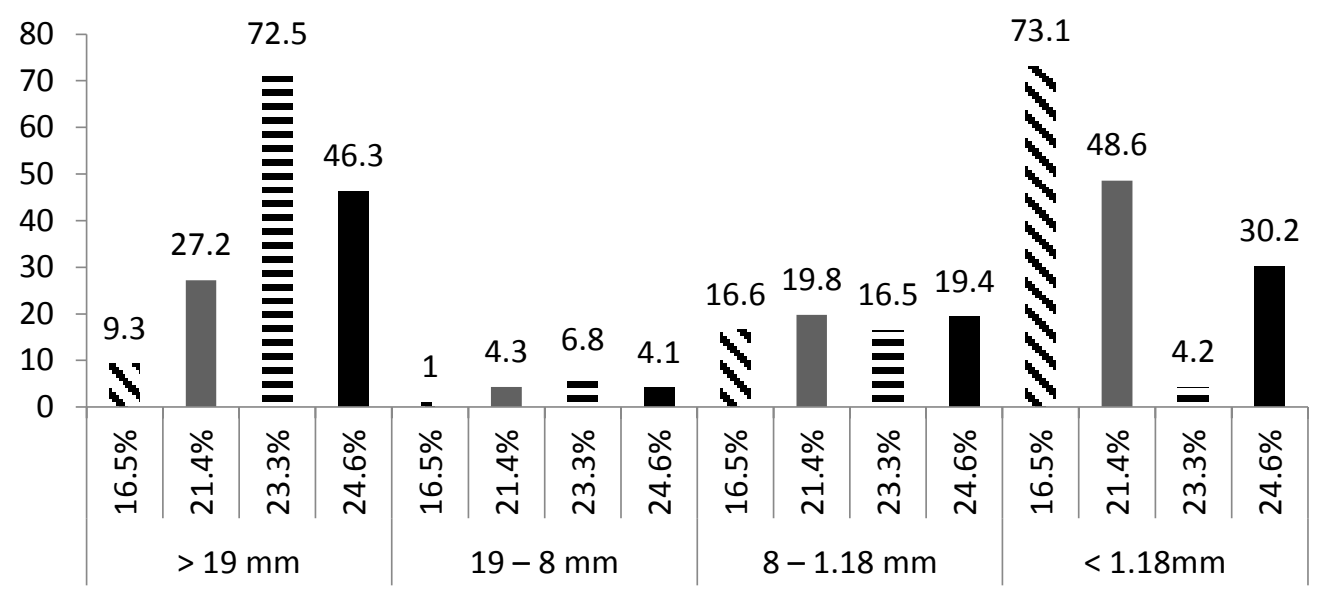

(C)

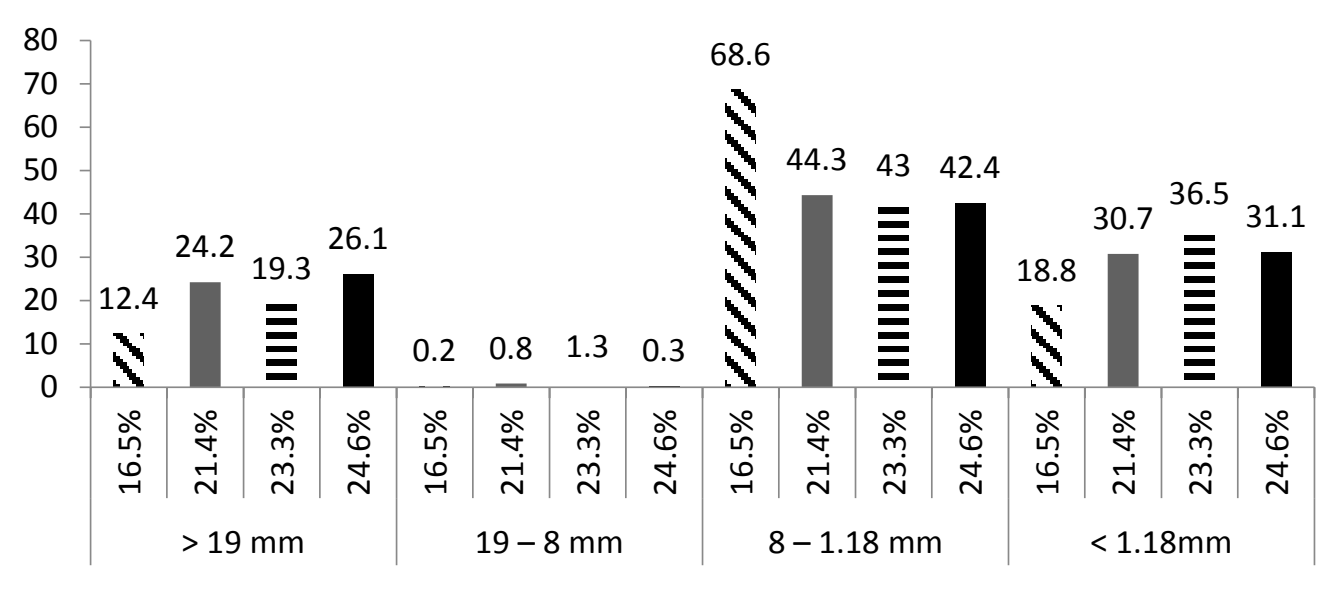
(1) D1
D2
$\equiv \mathrm{D} 3$
D4

Figure 1 Average particle size (\%) offered $(A)$, rejected $(B)$ and consumed $(C)$ for lambs fed diets providing $16.5 \%$ (D1), $21.4 \%$ (D2), 23.3\% (D3) and 24.6\% (D4) physically effective neutral detergent fibre 
Table 3 Performance and daily consumption of nutrients by finishing lambs fed diets formulated to provide various levels of physically effective neutral detergent fibre

\begin{tabular}{lllllll}
\hline & D1 & D2 & D3 & D4 & SE & $P$-value \\
\hline Intake, g/kg live weigt & & & & & & \\
$\quad$ Dry matter & 78.3 & 88.0 & 90.1 & 90.3 & 2.9 & $>0.05$ \\
$\quad$ Organic matter & 68.7 & 75.2 & 75.5 & 72.4 & 1.3 & $>0.05$ \\
$\quad$ Crude protein & $12.2^{\mathrm{c}}$ & $17.0^{\mathrm{a}}$ & $16.5^{\mathrm{a}}$ & $15.0^{\mathrm{b}}$ & 0.5 & $<0.05$ \\
$\quad$ Neutral detergent fibre & $22.5^{\mathrm{b}}$ & $28.9^{\mathrm{a}}$ & $29.7^{\mathrm{a}}$ & $29.6^{\mathrm{a}}$ & 1.2 & $<0.05$ \\
\hline Intake, \% live weight & & & & & & \\
$\quad$ Dry matter & 3.62 & 3.97 & 4.18 & 4.23 & 0.10 & $>0.05$ \\
$\quad$ Organic matter & 3.18 & 3.39 & 3.50 & 3.34 & 0.10 & $>0.05$ \\
$\quad$ Crude protein & $0.568^{\mathrm{c}}$ & $0.768^{\mathrm{a}}$ & $0.767^{\mathrm{a}}$ & $0.694^{\mathrm{b}}$ & 0.02 & $<0.05$ \\
$\quad$ Neutral detergent fibre & $1.04^{\mathrm{b}}$ & $1.30^{\mathrm{a}}$ & $1.38^{\mathrm{a}}$ & $1.36^{\mathrm{a}}$ & 0.10 & $<0.05$ \\
Average daily gain, g & 229 & 246 & 248 & 247 & 9.01 & $>0.05$ \\
Feed conversion & 3.50 & 3.92 & 3.69 & 3.71 & 0.14 & $>0.05$ \\
\hline
\end{tabular}

a,b,c With a row, means followed by a similar superscript were not different at probability $P=0.05$

D1, D2, D3, D4: diets providing $16.5 \%, 21.4 \%, 23.3 \%$ and $24.6 \%$ physically effective neutral detergent fibre, respectively

Table 4 Indexes of diet selection by lambs fed diets with various levels of physically effective neutral detergent fibre

\begin{tabular}{cccc}
\hline Diets & Index & Particle size & Index \\
\hline D1 & 84.2 & $<1.18 \mathrm{~mm}$ & $84.1^{\mathrm{a}}$ \\
D2 & 86.2 & $1.18-8 \mathrm{~mm}$ & $48.9^{\mathrm{b}}$ \\
D3 & 87.9 & $8-19 \mathrm{~mm}$ & $106.3^{\mathrm{a}}$ \\
D4 & 83.2 & $>19 \mathrm{~mm}$ & $100.8^{\mathrm{a}}$ \\
\multicolumn{4}{l}{, With a column, means followed by a similar superscript were not different at probability $P=0.05 ;$ SE $=3.3$} \\
D1, D2, D3, D4: diets providing 16.5\%, 21.4\%, 23.3\% and 24.6\% physically effective neutral detergent fibre, respectively
\end{tabular}

Table 5 Allocation of time by lambs fed diets that varied in the level of physically effective neutral detergent fibre

\begin{tabular}{|c|c|c|c|c|c|c|}
\hline Allocation of time & D1 & D2 & D3 & D4 & SE & $P$-value \\
\hline Intake (h/d) & 4.2 & 4.7 & 4.4 & 4.6 & 0.4 & $>0.05$ \\
\hline Rumination $(\mathrm{h} / \mathrm{d})$ & 6.2 & 7.3 & 6.3 & 6.9 & 0.2 & $>0.05$ \\
\hline Idle $(\mathrm{h} / \mathrm{d})$ & 12.7 & 11.1 & 12.4 & 11.7 & 0.1 & $>0.05$ \\
\hline Total mastication time $(\mathrm{h} / \mathrm{d})$ & 10.4 & 12.0 & 10.0 & 10.4 & 0.4 & $>0.05$ \\
\hline Rumination time/bolus (sec/bolus) & $26.4^{\mathrm{b}}$ & $34.7^{\mathrm{a}}$ & $32.8^{\mathrm{a}}$ & $34.4^{\mathrm{a}}$ & 0.9 & $<0.05$ \\
\hline Other activities $(\mathrm{h} / \mathrm{d})$ & 0.9 & 0.9 & 0.9 & 0.8 & 0.4 & $>0.05$ \\
\hline
\end{tabular}


Table 6 Rates at which dry matter and neutral detergent fibre were consumed and efficiencies associated with rumination and mastication

\begin{tabular}{lcccccc}
\hline Variable & D1 & D2 & D3 & D4 & SE & $P$-value \\
\hline Dry matter intake, g/d & 918 & 969 & 963 & 868 & 35 & $>0.05$ \\
Neutral detergent fibre intake, g/d & 236 & 304 & 305 & 289 & 13 & $>0.05$ \\
Feed intake efficiency, g/h & 223 & 220 & 241 & 190 & 16 & $>0.05$ \\
DM rumination efficiency, g/h & 151 & 136 & 184 & 128 & 11 & $>0.05$ \\
NDF rumination efficiency, g/h & 39.2 & 43.1 & 58.9 & 42.4 & 3.7 & $>0.05$ \\
Number of boluses/day & 845 & 755 & 689 & 720 & 35 & $>0.05$ \\
Rumination mastications/day & 3996 & 43262 & 36173 & 41760 & 2346 & $>0.05$ \\
Rumination mastications/bolus & 47.3 & 57.3 & 52.5 & 58.0 & 1.6 & $>0.05$ \\
& & & & & &
\end{tabular}

Intake is limited by energy requirements rather than rumen fill when the diet contains less than $50 \%$ to $60 \%$ NDF. Animals fed highly digestible diets tend to ingest their feed in less time than grazing animals and shortly after meeting their energy requirements feed intake decreases (Hall \& Mertens, 2017). In the present study, the mean time spent ingesting feed was relatively short. The short feeding time was probably a reflection that these lambs, which were fed in confinement, were able to satisfy their energy requirements quickly and without much need for selection among diet constituents. Kozloski et al. (2006, who fed confined lambs diets with low energy density and high levels of NDF, found the lambs spent approximately $50 \%$ more time ingesting feed than the lambs in the present study. This suggests that under these conditions intake rates depended largely on the animal's physiological status (Moyo et al., 2019).

As the roughage portion of the diet increased, so did rumination time (Van Soest, 1994; Cardoso et al., 2006). However, in the present study, even with NDF concentrations that exceeded the NRC (2007) recommendations for lambs, there was no measurable increase in time spent ruminating. Cardoso et al. (2006) reported that lambs increased time spent ruminating, up to $8.05 \mathrm{~h} / \mathrm{d}$, as dietary fibre concentration increased.

Differences in the time spent feeding and the time that feeding occurred are frequently observed in trials in which diet fibre concentration is variable (Mendes et al., 2010). This was demonstrated in lambs fed diets that were low in fibre in which they adapted to this condition by selecting a greater proportion of larger particles. This may have been an adjustment to greater concentrations of organic acids in the rumen from the rapid degradation rates of concentrate (Hall \& Mertens, 2017). If lambs fail to make this adjustment, rumen $\mathrm{pH}$ can be affected (Tedeschi et al., 2010). This indicates that lambs adjust selectivity to compensate for low dietary fibre concentration to maintain a healthy rumen environment with an adequate $\mathrm{pH}$. Regadas Filho et al. (2014) recommended a minimum level of $20 \%$ peNDF in the diet in lactating ewes or growing lambs,

Smaller APS can influence mastication activity and ruminal $\mathrm{pH}$ negatively in confined lambs. Conversely, larger APS can result in fibre component rejection with similar negative results to those in which diets contain insufficient fibre. In the present study, the greater time spent masticating by animals on D2, D3 and D4 was a direct result of larger APS in those diets compared with D1. In diets with lower levels of fibre time spent chewing was reduced, as was observed with D1. Others have shown that mastication time increased with NDF concentration, but declined with decreased APS (Hall \& Mertens, 2017). However, mastication time per kilogram of DM is not solely a factor of feed characteristics, but rather a cumulative effect of feed and animal.

\section{Conclusions}

Meaningful differences in performance and efficiency were not observed that were related to differences in peNDF among the diets. The trial indicated that diet APS does not affect lamb feed intake, short-term ADG and feeding behaviour because of compensatory selectivity by lambs.

\section{Acknowledgments}

The authors acknowledge the staff of the Department of Animal Production, Universidade Estadual Vale do Acaraú (UVA) for their assistance in animal care and feeding and the laboratory staff of the Small Ruminant Research Group, UVA, for their help in chemical analysis. 


\section{Authors' Contributions}

HHAC, MCPR and RCFFP designed the experiment and carried out the research trial. RNBL and ARL completed the statistical analyses. MCPR, LFG, CSC, ESP and JPM structured the scientific content and drafted the manuscript. All authors provided editorial suggestions and approved the final manuscript.

\section{Conflict of Interest Declaration}

The authors declare that there is no conflict of interest

\section{References}

Andrade-Lima, 1981. The Caatingas dominium. Rev. Bras. Botânica 4, 149-153.

AOAC, 1990. Official methods of analysis of AOAC AOAC 15, CD-ROM.

Araújo Filho, J.A. de., 2013. Manejo pastoril sustentável da Caatinga | Instituto Interamericano de Cooperação para a Agricultura (Projeto Dom Helder Camara, Ed.). 1st ed. Recife.

Bürger, P.J., Pereira, J.C., Queiroz, A.C. de, Coelho da Silva, J.F., Valadares Filho, S. de C., Cecon, P.R. \& Casali, A.D.P., 2000. Ingestive behavior in Holstein calves fed diets with different concentrate levels. Rev. Bras. Zootec. 29, 236-242. https://doi.org/10.1590/S1516-35982000000100031

Cardoso, A.R., Carvalho, S., Galvani, D.B., Pires, C.C., Gasperin, G. \& Garcia, R.P.A., 2006. Comportamento ingestivo de cordeiros alimentados com dietas contendo diferentes níveis de fibra em detergente neutro. Cienc. Rural 36, 604-609. https://www.scielo.br/scielo.php?pid=S0103-84782006000200038\&script=sci_abstract\&tlng=pt

Costa, H.H.A., Pinheiro Rogério, M.C., Muir, J.P., Alves, A.A., Galvani, D.B., Fernandes Franco Pompeu, R.C., Landim, A.V., de Souza Carneiro, M.S. \& Campos, W.É., 2013. Nutritional evaluation of lamb diets in a tropical setting formulated according to NRC (1985) and NRC (2007) specifications. Small Rumin. Res. 113, $20-29$. https://doi.org/10.1016/j.smallrumres.2013.02.003

Costa, H., Saliba, E., Galvani, D., Bomfim, M., Lana, Â.M., Borges, A.L., Landim, A. \& Faciola, A., 2019. Effects of zinc sulfate or propylene glycol on intake, digestibility, and forage selection by grazing sheep in a semi-arid region during the rainy season. Anim. 9 (11), 867. https://doi.org/10.3390/ANI9110867

Custodio, S.A.S., Tomaz, M.P., Silva, D.A.L., Goulart, R.O., Dias, K.M. \& Carvalho, E.R., 2016. Feeding behavior of beef cattle fed different forages and housed in individual or collective pens. J. Anim. Behav. Biometeorology 5, $20-28$. https://doi.org/10.14269/2318-1265/jabb.v5n1p20-28

Eustáquio Filho, A., Carvalho, G.G.P., Pires, A.J.V., Silva, R.R., Santos, P.E.F., Murta, R.M. \& Pereira, F.M., 2014. Ingestive behavior of lambs confined in individual and group stalls. Asian-Australas. J. Anim. Sci. 27, $284-289$. https://doi.org/10.5713/ajas.2013.13212

Francisco, A.E., Janíček, M., Dentinho, T., Portugal, A.P.V., Almeida, J.M., Alves, S.P., Fialho, L., Jerónimo, E., Bessa, R.J.B. \& Santos-Silva, J., 2020. Effects of alfalfa particle size and starch content in diets on feeding behaviour, intake, rumen parameters, animal performance and meat quality of growing lambs. Meat Sci. 161, 107964. https://doi.org/10.1016/j.meatsci.2019.107964

Gallo, S.B., Brochado, T., Ariboni Brandi, R., da Silva Bueno, I.C., Passareli, D., Birgel, D.B. \& Birgel Junior, E.H., 2019. Implications of low fiber levels in finishing lambs on performance, health, rumen, and carcass parameters. Trop. Anim. Health Prod. 51, 767-773. https://doi.org/10.1007/s11250-018-1750-0

Hall, M.B. \& Mertens, D.R., 2017. A 100-year review: Carbohydrates - characterization, digestion, and utilization. J. Dairy Sci. 100, 10078-10093. https://doi.org/10.3168/jds.2017-13311

Johnson, T.R. \& Combs, D.K., 1991. Effects of prepartum diet, inert rumen bulk, and dietary polyethylene glycol on dry matter intake of lactating dairy cows. J. Dairy Sci. 74, 933-944. DOI: 10.3168/jds.S0022-0302(91)78243-X

Kozloski, G.V., Trevisan, L.M., Bonnecarrère, L.M., Härter, C.J., Fiorentini, G., Galvani, D.B. \& Pires, C.C., 2006. Levels of neutral detergent fiber in lambs diets: Intake, digestibility and ruminal fermentation. Arq. Bras. Med. Veterinária E Zootec. 58, 893-900. https://doi.org/10.1590/S0102-09352006000500027

Lammers, B.P., Buckmaster, D.R. \& Heinrichs, A.J., 1996. A simple method for the analysis of particle sizes of forage and total mixed rations. J. Dairy Sci. 79, 922-928. https://doi.org/10.3168/jds.S0022-0302(96)76442-1

Leonardi, C. \& Armentano, L.E., 2003. Effect of quantity, quality, and length of alfalfa hay on selective consumption by dairy cows. J. Dairy Sci. 86, 557-564. https://doi.org/10.3168/jds.S0022-0302(03)73634-0

Leonardi, C., Shinners, K.J. \& Armentano, L.E., 2005. Effect of different dietary geometric mean particle length and particle size distribution of oat silage on feeding behavior and productive performance of dairy cattle. J. Dairy Sci. 88, 698-710. https://doi.org/10.3168/jds.S0022-0302(05)72734-X

Littell, R.C., Freund, R.J. \& Specter, P.C., 1991. SAS system for linear models. 3rd ed. Amazon.com.

Macedo Junior, G. de L., Pérez, J.R.O., Almeida, T.R. de V. e, Paula, O.J. de, França, P.M. de \& Assis, R. de M., 2006. Influência de diferentes níveis de fdn dietético no consumo e digestibilidade aparente de ovelhas Santa Inês. Ciênc. E Agrotecnologia 30, 547-553. https://doi.org/10.1590/s1413-70542006000300022

Medeiros, G.R. de, Carvalho, F.F.R. de, Ferreira, M. de A., Batista, Â.M.V., Alves, K.S., Maior Júnior, R.J. de S. \& Almeida, S.C. de., 2007. Efeito dos níveis de concentrado sobre o desempenho de ovinos Morada Nova em confinamento. Rev. Bras. Zootec. 36, 1162-1171. https://doi.org/10.1590/S1516-35982007000500025

Mendes, C.Q., Turino, V. de F., Susin, I., Pires, A. V., Morais, J. B. de \& Gentil, R. S., 2010. Lamb feeding behavior and nutrient digestibility of high concentrate diets with different neutral detergent fiber sources. Rev. Bras. Zootec. 39, 594-600. https://doi.org/10.1590/S1516-35982010000300019

Moreno, G.M.B., Silva Sobrinho, A.G., Leão, A.G., Loureiro, C.M.B., Perez, H.L. \& Rossi, R.C., 2010. Desempenho, digestibilidade e balanço de nitrogênio em cordeiros alimentados com silagem de milho ou cana-de-açúcar e dois níveis de concentrado. Rev. Bras. Zootec. 39, 853-860. https://doi.org/10.1590/S1516-35982010000400022 
Moyo, M., Adebayo, R.A. \& Nsahlai, I.V., 2019. Effects of diet and roughage quality, and period of the day on diurnal feeding behaviour patterns of sheep and goats under subtropical conditions. Asian-Australas. J. Anim. Sci. 32, 675-690. https://doi.org/10.5713/ajas.17.0901

Nicory, I.M.C., de Carvalho, G.G.P., Ribeiro, O.L., Silva, R.R., Tosto, M.S.L., Costa-Lopes, L.S., Souza, F.N.C. \& de Oliveira Nascimento, C., 2015. Ingestive behavior of lambs fed diets containing castor seed meal. Trop. Anim. Health Prod. 47, 939-944. https://doi.org/10.1007/s11250-015-0812-9

NRC, 1985. Nutrient requirements of sheep. 6th ed. National Academies Press, Washington DC.

NRC, 2007. Nutrient requirements of small ruminants. sheep, goats, cervids, and New World camelids. NA Press, Washington DC.

Polli, V., Restle, J. \& SENNA, D.O., 1996. Aspectos relativos à ruminação de bovinos e bubalinos em regime de confinamento. Rev. Bras. Zootec. 25.

Regadas Filho, J.G.L., Tedeschi, L.O., Cannas, A., Vieira, R.A.M. \& Rodrigues, M.T., 2014. Using the small ruminant nutrition system to develop and evaluate an alternative approach to estimating the dry matter intake of goats when accounting for ruminal fiber stratification. J. Dairy Sci. 97, 7185-7196. https://doi.org/10.3168/jds.2014-8632

Santos, M.V.F. dos, Lira, M. de A., Dubeux Junior, J.C.B., Guim, A., Mello, A.C.L. de \& Cunha, M.V. da, 2010. Potential of Caatinga forage plants in ruminant feeding. Rev. Bras. Zootec. 39, 204-215. https://doi.org/10.1590/S151635982010001300023

Schneider, B.H. \& Flatt, W.P., 1975. The evaluation of feeds through digestibility experiments. 1st ed. University of Georgia Press, Athens, USA.

Sniffen, C.J., O'Connor, J.D., Van Soest, P.J., Fox, D.G. \& Russell, J.B., 1992. A net carbohydrate and protein system for evaluating cattle diets: II. Carbohydrate and protein availability. J. Anim. Sci. 70, 3562-3577. DOI: 10.2527/1992.70113562x

Sousa, N.M., Oliveira, J.S., Silva, D.S., Santos, E.M., Medeiros, A.N., Ramos, J.P.F. \& Brito, E.A., 2018. Levels of neutral detergent fiber in diets with forage palm for dairy goats. Arq. Bras. Med. Veterinária E Zootec. 70, 15951604. https://doi.org/10.1590/1678-4162-10181

Tedeschi, L.O., Cannas, A. \& Fox, D.G., 2010. A nutrition mathematical model to account for dietary supply and requirements of energy and other nutrients for domesticated small ruminants: The development and evaluation of the small ruminant nutrition system. Small Rumin. Res. 89, 174-184. https://doi.org/10.1016/j.smallrumres.2009.12.041

Van Soest, P.J., 1994. Nutritional ecology of the ruminant. 2nd ed. Cornell University Press, Ithaca.

Van Soest, P.J., Robertson, J.B. \& Lewis, B.A., 1991. Methods for dietary fiber, neutral detergent fiber, and nonstarch polysaccharides in relation to animal nutrition. J. Dairy Sci. 74, 3583-3597. https://doi.org/10.3168/jds.S00220302(91)78551-2

Weiss, W.P., 1993. Predicting energy values of feeds. J. Dairy Sci. 76, 1802-1811. https://doi.org/10.3168/jds.S00220302(93)77512-8 